\title{
ハイス鋼上の鉄ータングステン合金めっき皮膜の付着性 および硬さ特性に及ぼす接合金属の影響
}

\author{
高野 孝和*a, 蓮覚寺聖一, 池野 進, 中村 優子, 島崎長一郎
}

\section{Influence of Binder Metals on the Adhesive Strength and the Surface Hardness in Fe-W Alloy Films Electrodeposited on the High-Speed Steel}

\author{
Takakazu TAKANO, ${ }^{* a}$ Seichi RENGAKUJI, Susumu IKENO, Yuuko NAKAMURA, \\ and Choichiro SHIMASAKI
}

\author{
富山大学工学部物質工学科（干930-8555 富山市五幅 3190) \\ Department of System Engineering of Materials and Life Science, Faculty of Engineering, Toyama University \\ (Gofuku, 3190, Toyama 930-8555, Japan) \\ a現在：橉不二越（干930-8511 富山市不二越本町 1-1-1） \\ Present address : NACHI Fujikoshi corp., (Fujikoshihonmachi, 1-1-1, Toyama 930-8511, Japan)
}

\section{Received August 3, 1998 ; Accepted November 16, 1998}

\begin{abstract}
In order to improve the cutting ability of drills or endmills, Fe-W alloy electroplating was used to increase the surface hardness of the machine tools. Furthermore, in order to increase the adhesive strength between the coated $\mathrm{Fe}-\mathrm{W}$ alloy films and the high-speed steel substrate, $\mathrm{Fe}, \mathrm{Co}$ and $\mathrm{Cu}$ were used as adhesives. Adhesive strength was measured by both scratch and indentation methods. After annealing at $550{ }^{\circ} \mathrm{C}$, the critical load at which the films pull out was increased by the use of the adhesives. The order of increasing adhesive ability was $\mathrm{Cu}, \mathrm{Fe}, \mathrm{Co}$ and binder-less. On the other hand, the surface hardness measured by dynamic hardness tester showed Co to be best, followed by Fe, binder-less, then $\mathrm{Cu}$. This suggests that $\mathrm{Fe}$ is thought to be the most suitable for the binder metal. Cross-sectional analysis by ESCA showed an extensive diffusion of $\mathrm{Cu}, \mathrm{Fe}$, and Co into the Fe-W alloy film and the high-speed steel.
\end{abstract}

Key Words : Electroplating, Fe-W Alloys, Adhesive Srength, Surface Hardness

\section{1 緒 論}

切削加工の分野では, 良好な切削性, 耐摩耗性, 耐熱性お よび耐溶着性などが工具材料に望まれている。この中で工具 性能を決定する最大因子は切削性であり，これを向上させる には表面硬度を高くする必要がある1,2). 実際, TiC, TiN 硬 質膜が工具に PVDによりコーティングされているが3), PVD技術は真空処理を必要とするためエネルギー消費が大 きく，またバッチ方式のため生産性が低いという久点がある。 一方，電気めっき法は耐食部品や耐摩耗部品に適用されてい るが, 工具への適用は特殊な場合4を除いて見られない.しか し，電気めっき法は低エネルギーシステムで，大量生産性に 優れているためその技術を切削工具人適用することは鬿力的 である，近年，切削狗物へ鉄一タングステン (以後 $\mathrm{Fe}-\mathrm{W}$ と 記す）合金めっき適用した報告が見られる5).

本研究では，高温まで硬度が低下しない $\mathrm{Fe}-\mathrm{W}$ 合金 ${ }^{6)} に$ 着

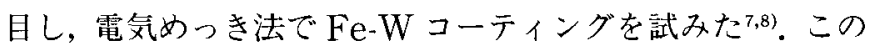
際，めつき膜と下地の八イス鋼 (SKH59) との付着性が機械 的強度の重要な要因であるので, 組成の異なる二つの材料の 接合金属にハイス鋼構成成分である Fe おょびCo や一般に 異種金属の接合に用いられる $\mathrm{Cu}$ を用いて，これらの接合金
属がめつき膜の付着力や表面硬度に与える影響を調べた.

\section{2 実験方法}

\section{1 試料の作成}

試料の模式図を Fig. 1 に, 試料作成手順を Fig. 2 に示す. また，皮膜付与のめっき条件を Table 2 に示す. Fig. 1 の素 地はハイス鋼 $(6 \mathrm{~mm} \times 6 \mathrm{~mm} \times 50 \mathrm{~mm}$, NACHI corp.) でその組成を Table 1 に示す，接合金属や Fe-W 合金をめ っきする際は，めっき面以外をブタジエンゴム（夕ーコ 59801-A，ニチュビルド社製)でマスキングした，ついで，1 $\mu \mathrm{m}$ アルミ十粉末 (メラー社製) で研磨し, 超音波洗浄, メ 夕ノール洗浄後直ちにめっきした. 接合金属として銅, 鉄, コバルトをそれぞれ $0.1 \mu \mathrm{m}$ の厚さになるようめっき後，水 洗し，次いで $\mathrm{Fe}-\mathrm{W}$ めっを行った。このときの $\mathrm{Fe}-\mathrm{W}$ 合金 皮膜の厚さは，断面の SEM 観察およびカロテスト法により 求め $2 \mu \mathrm{m}$ の厚みとなるように通電量を調節した。組成は波 長分散型 X 線分光器 (EPMA1500, (侏島津製) で求め, 夕 ングステン含有率 $23 \mathrm{wt} \%$ と一定になるよう Table 2 のめ つき条件を選んだ，ついで，試料を下地八イス鋼の硬度劣化 を引き起こさない $550{ }^{\circ} \mathrm{C} て ゙ 1$ 時間, $10^{-3} \mathrm{~Pa}$ の真空下で熱処 


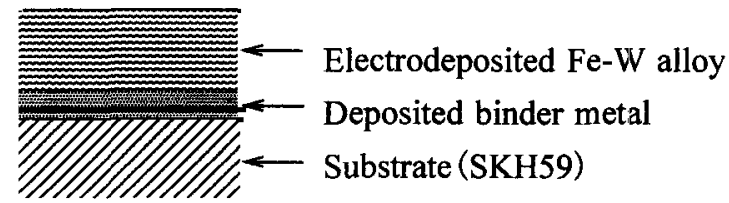

Fig. 1 Target structure of the specimen for improvement of the surface hardness and the adhesive strength in electrodeposited Fe-W alloy films on the high-speed steel(SKH59).

Table 1 Chemical composition of the high-speed steel.

\begin{tabular}{|ccccccccc|}
\hline $\mathrm{C}$ & $\mathrm{Mo}$ & $\mathrm{Co}$ & $\mathrm{Cr}$ & $\mathrm{W}$ & $\mathrm{V}$ & $\mathrm{Si}$ & $\mathrm{Mn}$ & $\mathrm{Fe}$ \\
\hline 1.1 & 9.5 & 8.0 & 4.0 & 1.55 & 1.15 & $<0.5$ & $<0.4$ & Bal. \\
\hline
\end{tabular}

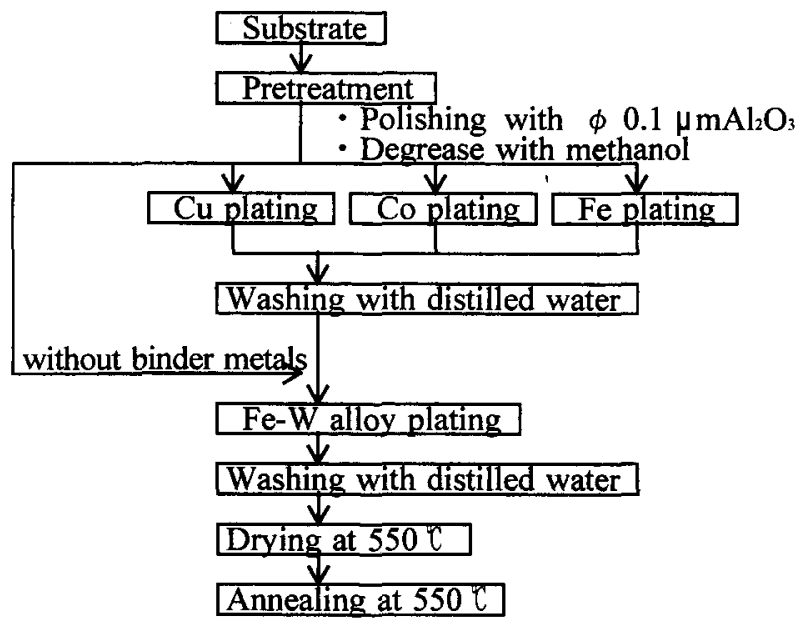

Fig. 2 Procedure for preparation of specimens improved by electrodeposition of $\mathrm{Fe}-\mathrm{W}$ alloy films on the high-speed steel with binder metals of $\mathrm{Cu}$, Co or Fe.

理した9).

\section{2 めっき厚さおよび組成}

めっき皮膜の厚さは，カロテスト法（簡易精密测定機 CALOTEST, CSEM 社製) によって测定した。この方法 は，ダイヤモンドパウダーを塗布した銅球を試料面上で回転 させ，皮膜を削り取った痕を顕微鏡で計測し，次式から皮膜 厚さを算出する方法である。

$$
h=(X-Y) \cdot(X+Y) \cdot 4 D^{-1}
$$

ここで, $D / \mathrm{mm}$ はボールの外径, $Y / \mathrm{mm}$ は素地痕の直 径, $X / \mathrm{mm}$ はめっき皮膜痕の直径, $h / \mathrm{mm}$ はめっき厚さ を表方。代表的測定例を Fig. 3 に示す，図から，明瞭に皮膜 の厚さが計測でき，SEM 断面観祭からの厚さと良く一致し たのでこの方法によって皮膜厚さを測定した。

\section{3 ESCA 分析}

接合金属あるいはめっき膜や素地金属が熱処理で拡散する 様子をXPS 法 (ESCA-1000, (株島津製) で調べた。剆定条 件は, $\mathrm{MgK} \alpha$ 線を用いて加速電圧 $8.0 \mathrm{kV}$, エミッション電流 $30 \mathrm{~mA}$ で深さ方向に分析した。この時のアルゴンイオンス
Table 2 Bath compositions and conditions of binder metals and $\mathrm{Fe}-\mathrm{W}$ alloy electroplating.

\begin{tabular}{l|c}
\hline \multicolumn{2}{c}{$\mathrm{Cu}$} \\
\hline $\mathrm{CuSO}_{4}$ & $20.8 \mathrm{~g} / \mathrm{dm}^{3}$ \\
$\left(\mathrm{NH}_{4}\right)_{2} \mathrm{SO}_{4}$ & $2.2 \mathrm{~g} / \mathrm{dm}^{3}$ \\
${ }^{*}$ DETA & $10 \mathrm{~g} / \mathrm{dm}^{3}$ \\
Bath temperature & $60{ }^{\circ} \mathrm{C}$ \\
Current density & $3 \mathrm{~A} / \mathrm{dm}^{2}$ \\
$\mathrm{pH}$ & 8.0 \\
\hline
\end{tabular}

\begin{tabular}{l|ll}
\hline \multicolumn{2}{c}{ Co } \\
\hline $\mathrm{Co}\left(\mathrm{CH}_{3} \mathrm{CO}_{2}\right)_{2}$ & $20 \mathrm{~g} / \mathrm{dm}^{3}$ \\
$\mathrm{NH}_{4} \mathrm{CH}_{3} \mathrm{CO}_{2}$ & $30 \mathrm{~g} / \mathrm{dm}^{3}$ \\
${ }^{*}$ DETA & $10 \mathrm{~g} / \mathrm{dm}^{3}$ \\
Bath temperature & $25{ }^{\circ} \mathrm{C}$ \\
Current density & $1 \mathrm{~A} / \mathrm{dm}^{2}$ \\
pH & 6.0 \\
\hline
\end{tabular}

\begin{tabular}{l|c}
\hline \multicolumn{2}{c}{$\mathrm{Fe}$} \\
\hline $\mathrm{FeSO}_{4}$ & $202.5 \mathrm{~g} / \mathrm{dm}^{3}$ \\
$\left(\mathrm{NH}_{4}\right)_{2} \mathrm{SO}_{4}$ & $105 \mathrm{~g} / \mathrm{dm}^{3}$ \\
$\left(\mathrm{NH}_{4}\right) \mathrm{Fe}\left(\mathrm{SO}_{4}\right)_{2}$ & $300 \mathrm{~g} / \mathrm{dm}^{3}$ \\
Bath temperature & $43 \mathrm{C}$ \\
Current density & $2 \mathrm{~A} / \mathrm{dm}^{2}$ \\
$\mathrm{pH}$ & 4.5 \\
\hline
\end{tabular}

\begin{tabular}{l|c}
\hline \multicolumn{2}{c}{$\mathrm{Fe}-\mathrm{W}$ alloy } \\
\hline $\mathrm{FeSO}_{4}$ & $0.2 \mathrm{~mol} / \mathrm{dm}^{3}$ \\
$\mathrm{Na}($ cit.) & $0.4 \mathrm{~mol} / \mathrm{dm}^{3}$ \\
$\mathrm{Na}_{2} \mathrm{WO}_{4}$ & $0.2 \mathrm{~mol} / \mathrm{dm}^{3}$ \\
Bath temperature & $60{ }^{\circ} \mathrm{C}$ \\
Current density & $2 \mathrm{~A} / \mathrm{dm}^{2}$ \\
pH & 3.5 \\
\hline
\end{tabular}

*DETA : Diethylenetriamine
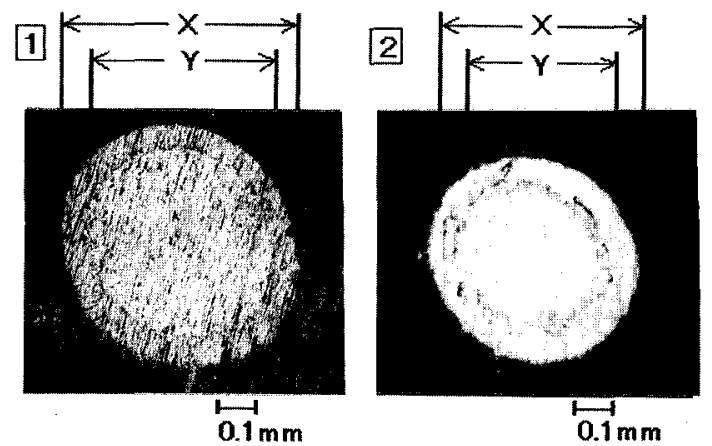

Fig. 3 Surface photographs of the specimens after CALOTEST. Specimen 1: With $\mathrm{Cu}$ binder metal, after annealing at $550{ }^{\circ} \mathrm{C}$. Specimen $2:$ With $\mathrm{Co}$ binder metal, after annealing at $550^{\circ} \mathrm{C}$

パッター速度は約 $7 \times 10^{-8} \mathrm{~m} \cdot \mathrm{min}^{-1}$ で, $2.5 \mathrm{~min}$ 毎に素地 の成分元素および接合金属の濃度分布を測定した。この際， 接合金属にハイス鋼とめっき皮膜の成分でない $\mathrm{Cu}$ を選び， 接合境界が明膫に現れる試料を選んだ. 


\section{4 付着力および表面硬度}

2. 4. 1 スクラッチ試験による付着力測定接合金属 による $\mathrm{Fe}-\mathrm{W}$ 皮膜と素地との付着力の評価は，スクラッチ試 験 (REVETEST, CSEM 社製)で行った，付着力の評価方 法は種々提案されているが10)，この方法は特に硬質膜に対し て有効と思われ，その測定原理は，めっき皮膜上を移動子る 半球状のダイヤモンド先端でめっき膜を押込みながら変形さ せ，膜が素地の変形に追従できなくなるまで押込み荷重を連 続的に増大させる。その結果，膜はフレーキングまたはチッ ピングを引き起こす。このときの荷重を臨界荷重と呼び，そ の時発生する音（アコースティックエミッション）で検出さ れる。この臨界荷重值が大きいほどをめっき皮膜との付着力 が大きい事になる。測定条件はダイヤモンド圧子の先端曲率 半径 $0.2 \mathrm{R}$, 先端角度 $120^{\circ}$, 最大負荷荷重 $20 \mathrm{~N}$, 負荷速度 20 $\mathrm{N} \cdot \mathrm{min}^{-1}$, 引っ搔き速度 $10 \mathrm{~mm} \cdot \mathrm{min}^{-1}$, 引っ搔き距離 2 $\mathrm{mm}$ である. 代表例を Fig. 4 に示す．横軸が負荷荷重，縦軸 がアコースティックエミッションの強度を表している。めつ き皮膜上を圧子が連続荷重下で移動させたとき，荷重 $1.6 \mathrm{~N}$ で皮膜が破壊されている事がわかる。このスクラッチ試験に より生じた皮膜の傷を観察したものを Fig. 5 に示す.Fig. 4 と Fig. 5 を比較すると，ダイヤモンド先端が押込まれた起点 から皮膜が破壊された点までの距離が，Fig.4のアコーステ イックエミッションの強度の急激な立ち上がりの荷重值と対 応し，付着力を評価する方法としての妥当性を与えていると 考えられる。

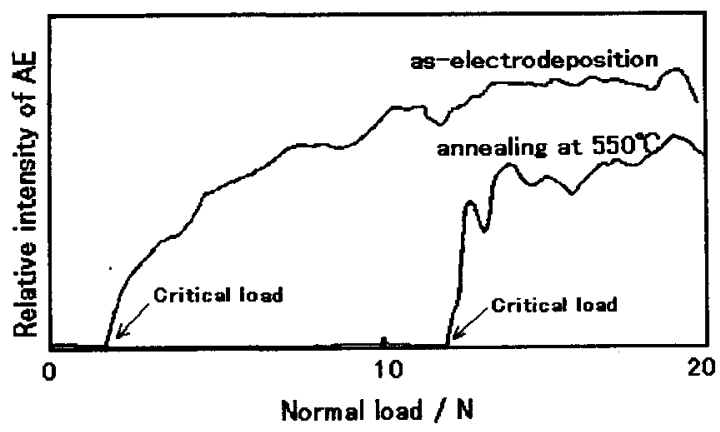

Fig. 4 Scratch test patterns of the electrodeposited Fe-W alloy film with binder metal of $\mathrm{Cu}$.

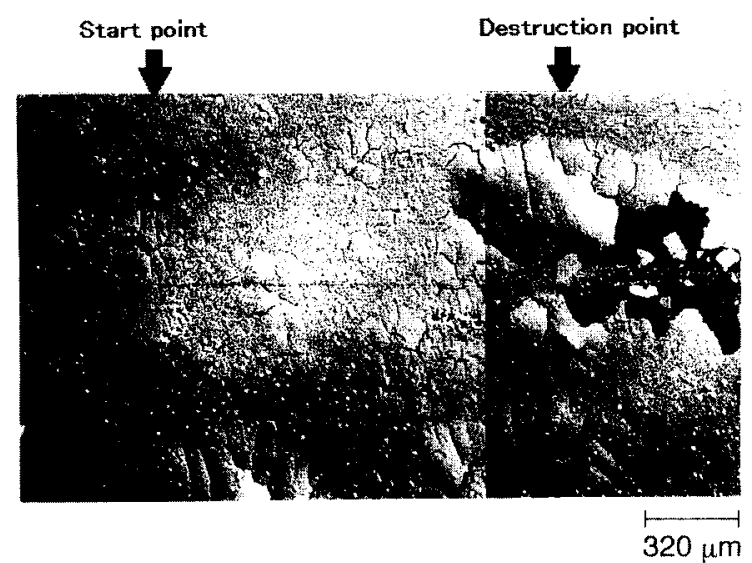

Fig. 5 SEM photograph of the specimen shown in Fig. 4.
2. 4. 2 押し込み硬さ試験による表面硬度押し込み 硬さ試験は，従来から用いられているマイクロビッカース硬 度計（微小硬度計）の原理を応用したものである，従来の微 小硬度計は，ビッカース圧子を試料表面（皮膜表面）に一定 荷重で押し込んで保持し，荷重を除荷した後で，変形した圧 痕の対角線を測定して硬さに換算する。この一定荷重を連続 荷重に变換したものが押し込み硬さ試験機（ダイナミック硬 度計）と呼ばれるもので，圧痕の寸法を計測するのではなく， 圧子の押し込んだ深さの変位を荷重の負荷時と除荷時に計测 し, 薄膜の㴊性, 硬さの評洒に用いられる方法である。試験 にはダイナミック微小硬さ試験機（フィッシャー製）を用い， $136^{\circ}$ の対面角度のビッカース圧子で, 最大 $500 \mathrm{mN}$ で测定し た。すなわち, 弾性領域内での材料表面の変形は荷重の開放 とともに回復するが，材料表面が破壊されるか塑性変形を起 こしな時, 変形は回復しない。めっき膜の場合でも, 素地と の付着力の程度によって変形の回復に差異が生じる。この差 異を硬度およびヤング率の差異として求め, 次式によってそ れぞれ圧子によって生じた圧こんの染さおよび面積から膜の 硬さとヤング率を求めた。しかし，これらの数值は下地 （SKH59）の影響を受ける。通常, ビッカース硬さは, 次式 で定義される.

$$
H=0.102 F \cdot S^{-1} \quad(\mathrm{MPa})
$$

ここで， $H$ 㞲硬度， $F / N$ は荷重， $S / \mathrm{mm}^{2}$ は圧こんの面 積である。また，ヤング率も次式から求められる。

$$
F \cdot S^{-1}=E \cdot \varepsilon
$$

ここで, $E$ はヤング率， $\varepsilon / \mathrm{mm}$ は压子の変位である.

\section{3 結果と考察}

種々の試料のめっき厚さは約 $2 \mu \mathrm{m}$ 程度と一定であるの で，接合金属の違いが皮膜の硬さや付着力に及ぼす影響を比 較評価できると考えられる。

\section{1 スクラッチ試験による付着力測定}

Fig. 6 に接合金属の違いによるスクラッチ試騃の結果を 示す。压子が移動する表面は，同じ条件で作成された $\mathrm{Fe}-\mathrm{W}$ めっき膜なので表面の凸凹度も同程度と見なし，表面が圧子

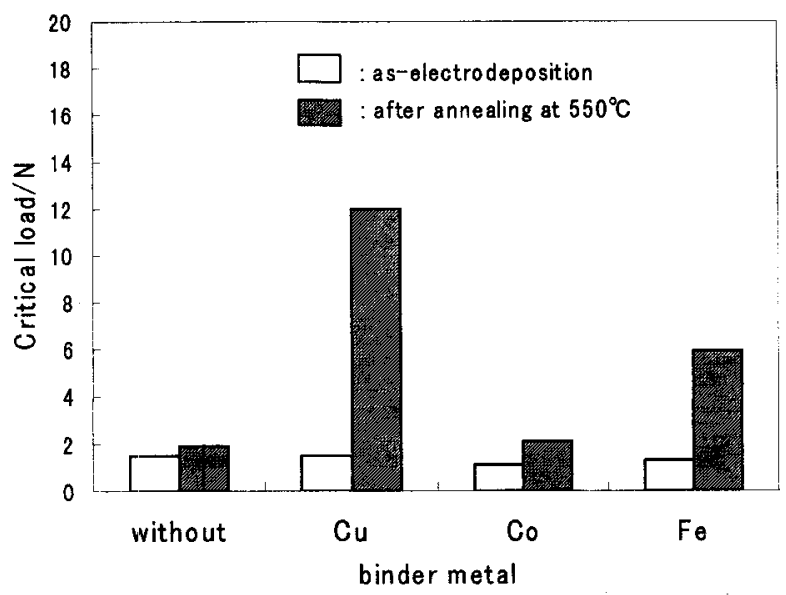

Fig. 6 Relation between Critical loads and binder metals. 
に与える影響を同等とした。いずれの試料においても, 熱処 理後に付着力が大きくなる。これは，接合金属のない試料も 熱処理後に付着力が大きくなっていることから，熱処理によ って付着力が向上する事を示している，しかし，熱処理によ る付着力の増加は, 接合金属種によって異なり, 接合金属と して Cuを用いた時付着力が最も大きくなった，次いで Fe， Coの順で付着力が向上した. 熱処理による付着力向上は, 接 合金属がめっき層や下地金属に熱拡散したため生じたと推定 し, 試料の深さ方向に接合金属が拡散しているかどうかを ESCA で分析した. Fig. 7 に深さ方向の ESCA パターンを 示す。横軸がスパッ夕ー時間，縦軸がピーク強度でそれぞれ 試料表面からの深さと成分元素の濃度に対応する. Fig. 7(a) は熱処理前, Fig. 7(b) が熱処理後の試料の分析結果である. めっき皮膜とハイス鋼素地と $\mathrm{Cu}$ 下地との界面での $\mathrm{Cu}$ の濃 度分布を比べる，熱処理後にはその分布が緩やかになり銅 が Fe-W 膜の方向へ拡散している，一方，めっ皮膜構成成

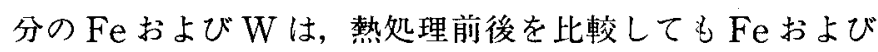
$\mathrm{W}$ の濃度に顕著な差が認められない，よって, Fe と W 元素 は，拡散し難いと言える。実際，Wは熱拡散し難いことが知 られており ${ }^{11)}$, その検出位置を下地とめっき膜の境界面とし た. Fig. 8 に Cu, Fe, W の深さ方向の XPS 測定結果を示 す. Cu は試料面から深さ方向にスパッターが進行していく と，熱処理前よりも熱処理後に浅い位㯰から現れることから， 熱処理による $\mathrm{Cu}$ の拡散を検証できる，金属間化合物の生成 の有無については，熱処理後の Feは，金属である $2 \mathrm{p} 3 / 2$ の 結合エネルギー值 $707.2 \mathrm{eV} / \mathrm{div}$ おび Fe2p1/2 結合エネ

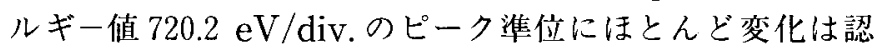
められず，また，サテライトピークも観測されなかった．熱 処理後の W は，金属である $4 \mathrm{f} 7 / 2$ の結合エネルギー值 31.0 $\mathrm{eV} / \mathrm{div}$.および $4 \mathrm{f} 5 / 2$ の結合エネルギー値 $33.0 \mathrm{eV} / \mathrm{div}$. が 認められ, 酸化物の $4 \mathrm{f} 7 / 2$ の結合エネルギー值 $35.6 \mathrm{eV} /$ div.および $4 \mathrm{f} 5 / 2$ の結合エネルギー値 $37.6 \mathrm{eV} / \mathrm{div} . の 4$ 個の分離したピークが存在する。これは，W が酸素と結合し やすく, $10^{-3} \mathrm{~Pa} の$ 真空下でも熱処理によって酸化されたこと を示している，従って，金属間化合物の生成は認められない。

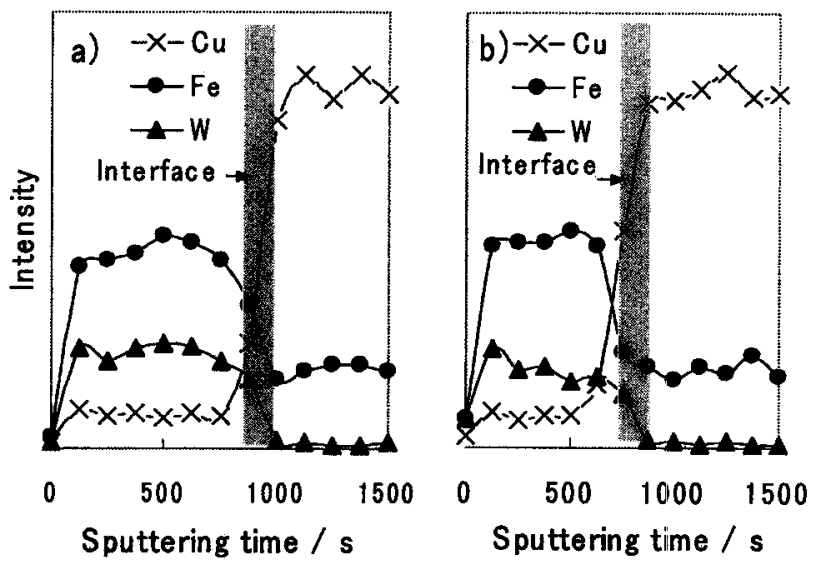

Fig. 7 XPS depth profiles of Fe-W alloy films electrodeposited on a $\mathrm{Cu}$ plate.

a) as-electrodeposition, b) annealing at $550{ }^{\circ} \mathrm{C}$.
ハイス鋼の成分は, Fe 74.7 wt\%であるので, Fe-W 合金膜 と共通の $\mathrm{Fe}$ を成分とする. 従って, 熱処理によって $\mathrm{Fe}$ が相 互拡散し，550 ${ }^{\circ} \mathrm{C}$ の低温でも $\mathrm{Cu}$ がハイス鋼主成分の $\mathrm{Fe}$ 一 拡散していると予想される。一方，めっき膜中へもこれらの 接合金属が拡散することを ESCA で確かめた（Fig. 7，8） ので, Coおよび Fe 接合金属も同様に，八イス鋼下地への熱 拡散が起きると推定される。よって，接合金属を中間にめっ きすることにより付着性が向上するのはその熱拡散の効果に よると推定できる.また, Fig. 9 に Fe おうよ゙Co 金属素地上 の $\mathrm{Fe}-\mathrm{W}$ 合金膜の $\mathrm{ESCA}$ パターンを示す. Fig. 9 から $\mathrm{Fe}$ または Co 接合金属の場合も $\mathrm{Fe}-\mathrm{W}$ 合金膜への拡散が認め られ，物理的な拡散によって $\mathrm{Cu}$ と同様に付着性が向上した と思われる. Fe-W 合金の硬度をビッカース硬さで $2000 \mathrm{Hv}$ にするために必要な熱処理温度は, $800{ }^{\circ} \mathrm{C}$ 程度であることが 知られているが，八イス鋼の熱処理温度で決まる $550{ }^{\circ} \mathrm{C} の$ 低 い熱処理温度でも接合金属の熱拡散によって付着力の向上が 期待できることが判った。

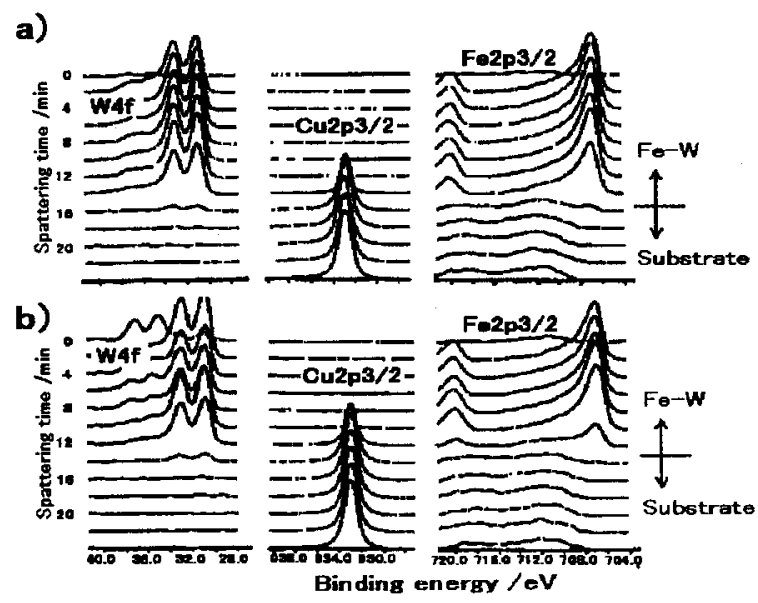

Fig. 8 XPS spectra of W4f, Fe2p / 3 and Cu2p3 / 2 levels for $\mathrm{Fe}-\mathrm{W}$ alloy films electrodeposited on a $\mathrm{Cu}$ plate, a) as-electrodeposition, b) annealing at $550{ }^{\circ} \mathrm{C}$.
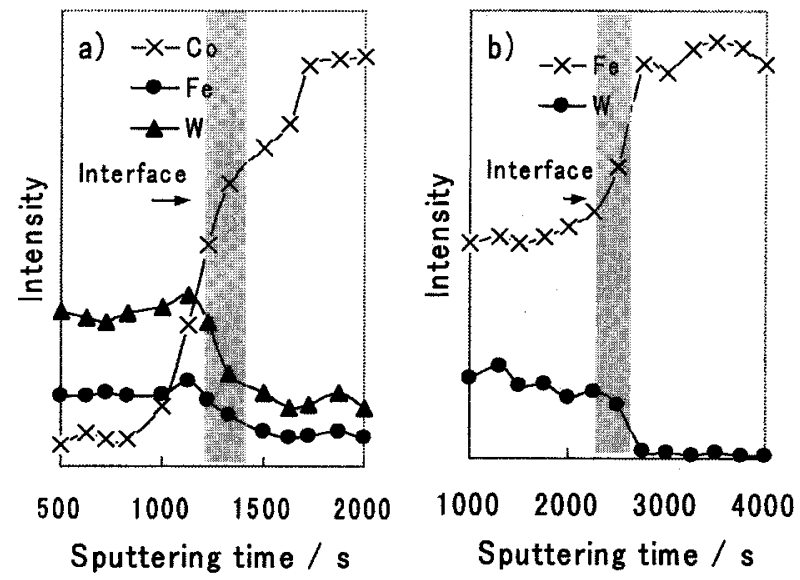

Fig. 9 XPS depth profiles of $\mathrm{Fe}-\mathrm{W}$ alloy films electrodeposited after annealing at $550{ }^{\circ} \mathrm{C}$, a) on a Co plate, b) on a Fe plate. 

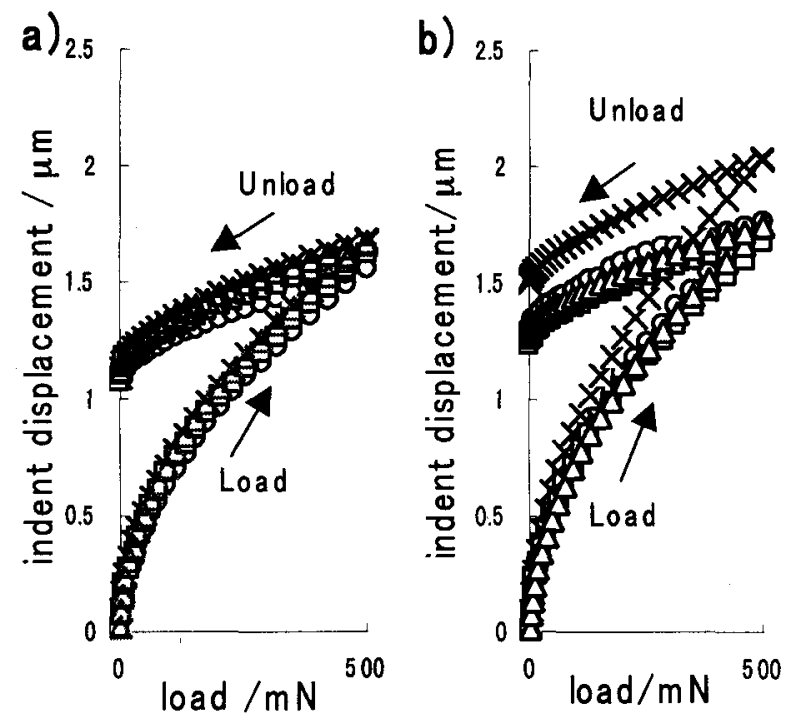

Fig.10 Load-displacement curves obtained by the dynamic hardness tester, a) as-electrodeposition, b) annealing at $550^{\circ} \mathrm{C}, \times: \mathrm{Cu} ; \bigcirc$ : without $\triangle \triangle \mathrm{Fe} ; \square: \mathrm{Co}$.

\section{2 押込み硬さ試験による表面硬度}

微小押し込み硬さ試験機により, 荷重を最大 $500 \mathrm{mN}$ まで 増加させた時のダイヤモンド圧子の侵入深さと最大荷重 500 $\mathrm{mN}$ から減少させる除荷時のダイヤモンド圧子の侵入深さ を測定しな結果を Fig. 10 に示す. 荷重と変位が直線的にな らないのは皮膜弾性の影響であり，除荷曲線が負荷曲線と重 ならないのは塑性変形が起きているためである。負荷曲線は， 皮膜の弾性変形と塑性変形との複合効果による变形を示すと 考えられる。ところで, 表面皮膜の硬さは深さ方向に押込み 過程の各点で荷重 $F$ と压子の深さ $d$ から形式的に式 $[2]$ 上 り計算される. 圧子の接触面積 $S$ は, 正四角錐の対面角 $136^{\circ}$ より $S=26.43 d^{-2}$ より求められる.よって, Fig.10 硬さ一 変位線図に変換した結果を Fig.11に示す。

Fig.10は, 压子の侵入深さが小さいと皮膜の変形が小さ く, 侵入深さが大きいと皮膜の変形が大きいことから, 同一 荷重において接合金属の違いによるめつき皮膜の変形の比較 ができる.熱処理前では, 浸入深さは接合金属を $\mathrm{Cu}, \mathrm{Co}, \mathrm{Fe}$ と変えた時 $\mathrm{Fe}>\mathrm{Co}>\mathrm{Cu}$ の順に小さくなった，一方熱処理 後では，浸入深さは $\mathrm{Cu} \gg \mathrm{Fe}>\mathrm{Co}$ の順に小さくなる傾向を 示すが, $\mathrm{Cu}$ は極端に浸入深さが大きい. Fe, Co では, 接合 金属のない場合よりも侵入深さが小さくなるが $\mathrm{Cu}$ は熱処理 と無関係に大きい。これは，接合金属が表面のめつき皮膜の 圧子による変形に影響を与えていることを示している，図の 除荷初期の弾性変形中において, 荷重と圧子の侵入深さの関 係が直散的になっていることから，接合金属と Fe-W めっき 膜およびハイス鋼素地が付着性が良く連続的な材料になって いると言える。

Fig.11は, 熱処理により何れの接合金属を用いても硬さが 小さくなることを示している．熱処理の前後で硬さを比較す ると, 接合金属なしのめっき皮膜は, 硬さは同程度に小さく なっている. Fe と Co は熱処理後において，押込み哚さが小 さい場合に比べて押込み深さが大きくなると，硬さが小さく
なる．Cuは逆に押込み深さが浅い場合に硬さの小さくなる 程度が小さいが押込み深さが染くなると，硬さが小さくなる 程度が大きい。これは，Feと Co はめっき皮膜を硬くする が, $\mathrm{Cu}$ はめっき皮膜を柔らかくすることを示している．压 子の深さが膜厚の $1 / 10$ 1/ 5 以下であれば素地の影響は無 視される ${ }^{12)}$. 実際, 素地よりも柔らかい $\mathrm{Cu}$ でも素地の影響は 認められない。硬さは押し込み深さの増加に伴い減少する傾 向を示し，めっき皮膜表面が皮膜内部よりも硬いことが判る. ごく表面では硬度以外の要因の影響で硬度が高くなっている

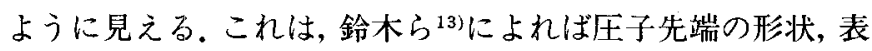
面の凸凹，酸化皮膜等の影響であり押し込み深さが表面から $50 \mathrm{~nm}$ まで影響するとしても，めっき皮膜の表面がめっき内 部よりも硬いことは明らかである。最大荷重 $500 \mathrm{mN}$ 時の硬 さ，下地および表面の影響を受けない皮膜自体の硬さを示す と考えられる荷重 $200 \mathrm{mN}$ 時の硬さ, 通常の硬さ測定に用い られる除荷後の圧こん寸法から求如た硬度 (塑性硬さ)，そし て弾性定数を Table 3 に示す.また, 皮膜のヤング率は, [ 3$]$ 式から求めた。この際, Fig.10に示守荷重一変位線図の除荷 初期の変形将弾性変形として, 荷重 $500 \mathrm{mN}$ から $460 \mathrm{mN}$ に除荷した美を $F$ ，そのときの圧子の変位を 接触面積を $S$ として計算した。また，圧子の押込み寸法は除 荷後の圧こん寸法よりも大きくなるために，計算されたビッ カース硬さが小さくなる。この小さくなる度合いを弾性変形
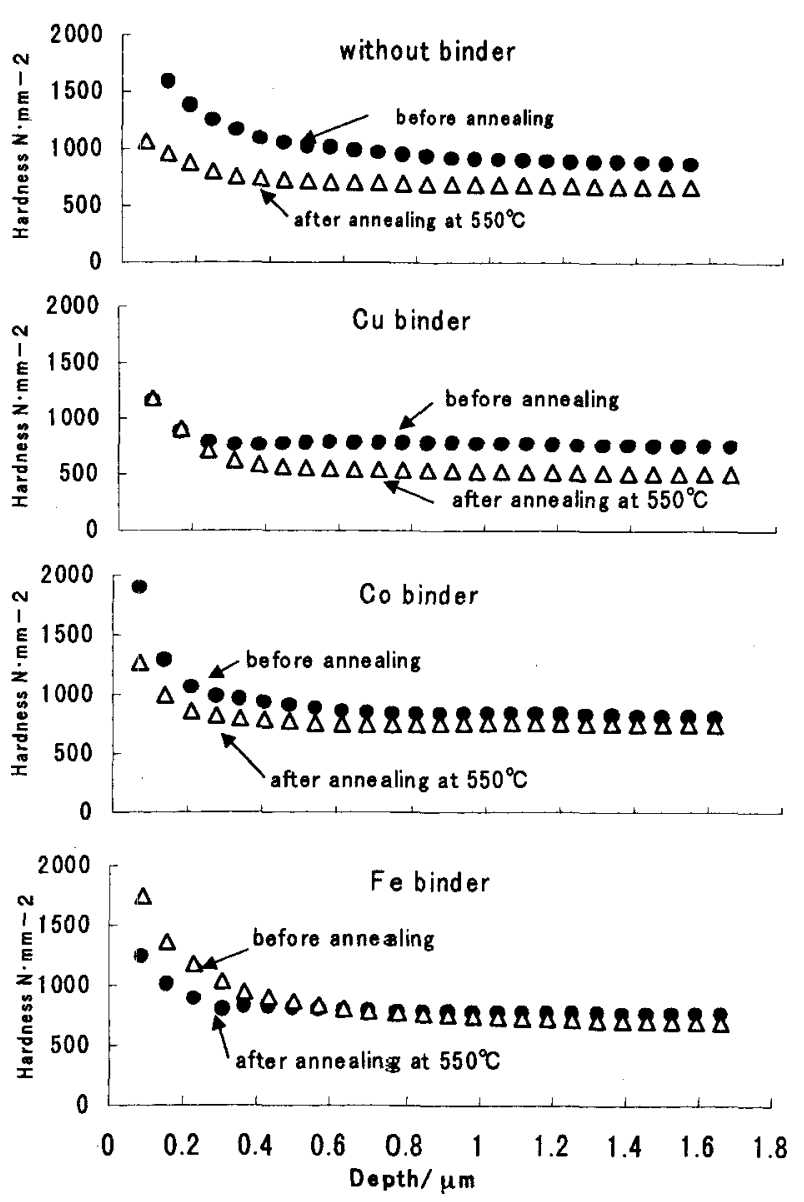

Fig.11 Relationship between hardness and indent displacement obtained by the dynamic hardness tester, before annealing ; $\triangle$ : after annealing at $550^{\circ} \mathrm{C}$. 
Table 3 Changes of surface characters by heat treatment.

\begin{tabular}{cccccrrrr}
\hline Binder metal & \multicolumn{2}{c}{ Without } & \multicolumn{2}{c}{$\mathrm{Cu}$} & \multicolumn{2}{c}{ Co } & \multicolumn{2}{c}{ Fe } \\
\hline Annealing at $5500^{\circ} \mathrm{C}$ & Before & After & Before & After & Before & After & Before & After \\
\hline Plastic Hardness / MPa & 1739 & 1237 & 1755 & 925 & 1801 & 1360 & 1668 & 1264 \\
Hardness at $200 \mathrm{mN} / \mathrm{MPa}$ & 910 & 686 & 767 & 522 & 832 & 758 & 765 & 731 \\
Hardness at $500 \mathrm{mN} / \mathrm{MPa}$ & 866 & 666 & 741 & 503 & 795 & 738 & 755 & 685 \\
Young's modulus & 231 & 228 & 179 & 137 & 207 & 227 & 199 & 207 \\
Elastic recovery (\%) & 50.2 & 46.2 & 57.8 & 45.6 & 55.9 & 45.7 & 54.8 & 45.8 \\
\hline
\end{tabular}

回復率として次式から計算し, Table 3 に示す.

$$
R=(H p-H i) / H p \times 100 \quad(\%)
$$

ここで, $H p$ は除荷後の圧こんから求めた硬さ, $H i$ は最大荷 重時の圧子の侵入深さから求めた硬さを示す. Table 3 か ら，押し込み硬さは最大荷重 $500 \mathrm{mN}$ で, $\mathrm{Co}>\mathrm{Fe}>$ 接合金 属無>Cuの順に硬さに差異を生じた。 $200 \mathrm{mN}$ ではCo> $\mathrm{Fe}>$ 接合金属無>Cuの順であり, 最大荷重 $500 \mathrm{mN}$ と同じ 傾向を示し，荷重の差による押込み硬さの差も $200 \mathrm{MPa}$ 程 度で同じである。いずれの接合金属でも表面に近い程押込み 硬さが大きくなる．これは，めっき皮膜の弾性変形に依る影 響と推定される．弾性変形回復比率は，熱処理前では接合金 属の種類により異なるが熱処理後ではその差がみられない (Table 3). 熱処理後の押し込み硬さの違いは, 主として接 合金属の硬さに依ると思われる。

エネルギー的な観点から，付着力はUずみエネルギーと関 係することが知られている，すなわち，強く素地と結合すれ ば，界面で皮膜にひずみを生じ，ひずみエネルギーは大きく なる、ひずみエネルギー, はは皮膜面に垂直に応力が加えられ な場合には，次式で与えられる14)。

$$
u=p^{2} \cdot(2 E)^{-1}
$$

ここで， $E$ は皮膜のヤング率， $p$ は加えられた応力である. このように，ヤング率の逆数が大きくなればひずみエネルギ 一が大きくなり，付着力を評価できる，硬さ测定における荷 重一変位線図から求めたヤング率（Table 3）とスクラッチ 試験で得られる臨界荷重の関係を，縦軸にヤング率の逆数を 取って Fig.12 に示す. Cu が付着性に寄与している効果が他 より大きいことがわかる.Fig.13は, $500 \mathrm{mN}$ 荷重時の硬さ (Table 3) と臨界荷重との関係を示す，硬さは, $\mathrm{Co}>\mathrm{Fe}>$ 接合金属無>Cuの順にであることからこれは，これらの金 属の硬さが影響していることを示している，表面硬度を高く する場合，接合金属の硬度を高くする必要があることがわか る，硬さと付着性を考虑したとき $\mathrm{Fe}$ が接合金属として最適 である. Cu は付着性向上に良いが表面硬さを低下させる。

\section{4 結 論}

ハイス鋼上の $\mathrm{Fe}-\mathrm{W}$ 合金めっき皮膜の付着性向上のため に中間に $\mathrm{Cu}, \mathrm{Co}, \mathrm{Fe}$ の接合金属膜を形成し，その効果を検 討した結果を示す.

（1）付着力評価としての臨界荷重值は，接合金属膜によって 異なり，その付着性は熱処理後で $\mathrm{Cu}, \mathrm{Fe}, \mathrm{Co}$, 接合金属 無の順であった。

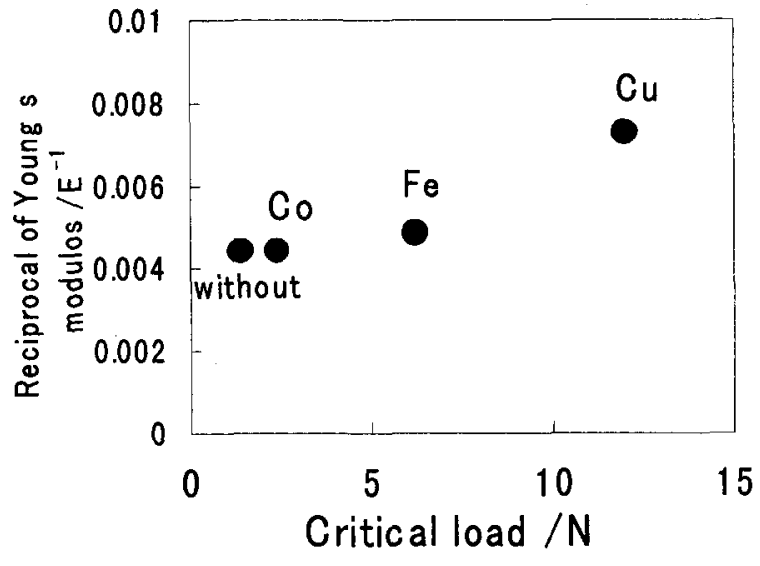

Fig.12 Relation between the critical load and the reciprocal of Young's modulus in electrodeposited Fe-W alloy films after annealing at $550{ }^{\circ} \mathrm{C}$.

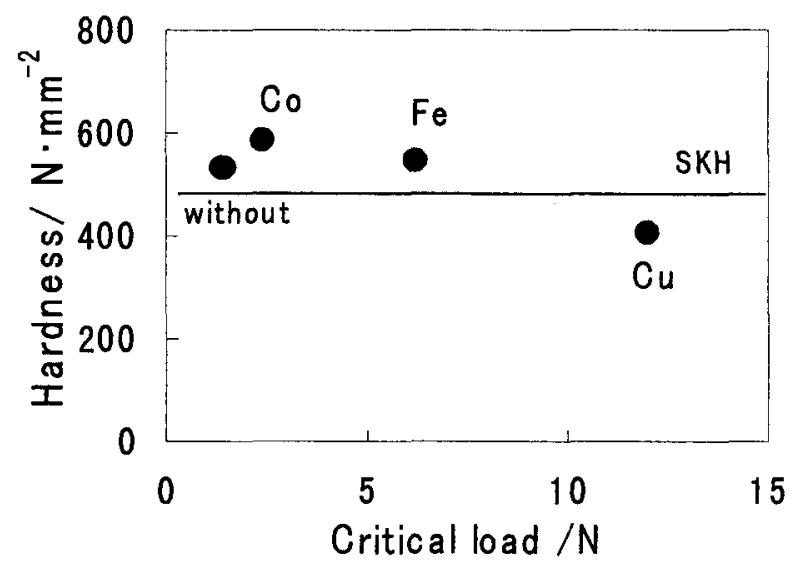

Fig.13 Correlation between the critical load and the hardness in electrodeposited Fe-W alloy films after anneal. ing at $550^{\circ} \mathrm{C}$.

（2）表面皮膜硬度は，接合金属によって影響され， $\mathrm{Co}>\mathrm{Fe}>$ 接合金属無 $>\mathrm{Cu}$ の順であった. (1)の結論と合わせて，接合 金属が皮膜の硬さと付着性に影響を与える。 また, ESCA 測定から $\mathrm{Cu}, \mathrm{Co}$ おび Fe 接合金属のいずれも Fe-W 合 金膜またはハイス鋼下地へ熱拡散する様子を確認した。

(3) 工具への適用に際して, 硬さと付着性の両面から接合金 属を評価すると, Feが最適である。

\section{文 献}

1) 切別加工技術便覧，日刊工業新聞社，147 (1970). 
2) 松永正久，金属表面技術，35，125 (1984).

3) C. Subramanian and A. N. S trafford, Wear, 165, 85 (1993).

4) 精密工学会, 表面改質に関する調査研究分科会編, 表面改質技 術一ドラスプロセスとその応用一，日刊工業新聞社，p.277 (1988).

5）渡辺 徹, 渡辺将志, 表面技術, 48, 549 (1997).

6) 渡辺 徽, 掛川正幸, 金属, 63 (7), 71 (1993).

7) 平田貴之, 蓮覚寺聖一, 中村優子, 平成 7 年電気学会協会北陸 支部秋期大会講演要旨集, 31 (1995).

8）蓮覚寺聖, 中村優子, 平田貴之, 技術·教育研究論文誌, 5 (1), 27 (1995).
9) JIS G4403-1983, 高速度工具鋼鋼材, 日本規格協会, 解 17 (1983).

10）薄膜の密着性測定法調査委員会報告「セラミックス系新素材 の性能評価に関する調査研究」，社ニューガラスフォーラム, 平成 6 年 3 月.

11) 中村勝吾, 表面の物理, 共立出版社, 136 (1970).

12) F. Frohlich, P. Grau, and W. Grellmann, Phys. Stat. Sol., (a) 42, 79 (1979).

13）鈴木敬愛，大村孝仁，トライポロジスト， 40 (3), 207 (1995).

14) 岡村弘之, 線形破壊力学入門, 培風館, 59 (1981). 